\title{
Assessment of the Water Quality of the Oti River in Ghana
}

\author{
A. Abdul-Razak ${ }^{1 *}$, A. B. Asiedu², R. E. M. Entsua-Mensah ${ }^{1}$ and K. A. A. deGraft-Johnson ${ }^{1}$ \\ ${ }^{1}$ CSIR-Water Research Institute, P. O. Box M.32, Accra, Ghana \\ ${ }^{2}$ Department of Geography and Resource Development, University of Ghana, Legon, Accra, Ghana \\ *Corresponding author; E-mail: razaknet@yahoo.com
}

\begin{abstract}
Oti river, an important tributary of the Volta lake in Ghana, was chosen as a case study to investigate the variations in the quality of its water at different locations. This was necessitated by the people's reliance on the river for their domestic and agricultural water use. Composite water samples drawn from some sections of the Oti river were analysed in the laboratory for certain parameters to enable assessment of water quality. The observed results of the laboratory analyses are compared with the 2003 Ghana Raw Water Criteria and Guidelines for domestic use. The results indicated that turbidity, total iron, faecal coliforms and total coliforms were above the limits set out by the 2003 Ghana Raw Water Criteria and Guidelines for domestic use. Thus, the water from Oti river was considered unsuitable for direct human consumption at the sampled locations. Using the Water Quality Index (WQI) Calculator 1.0, the WQI for Oti river was calculated to be 39.3. The WQI indicates that water quality in the Oti river was poor. This implies that the water quality is almost always threatened or impaired; conditions usually depart from natural or desirable levels. Public awareness with respect to the need to boil and/or filter the water before drinking is called for. Sanitary facilities to control river pollution and appropriate water treatments techniques are required in the area to improve the welfare of the riparian dwellers.
\end{abstract}

\section{Introduction}

Water quality monitoring is an essential tool used by environmental agencies to gauge the quality of surface water and to make management decisions for improving or protecting the intended uses. The Oti-arm of the basin contributes up to about $40 \%$ of the total volume of water in the Volta lake (Moxon, 1968; GEF-UNEP, 2002.). Evaluations of Oti river water quality conditions are often limited in scope and spatial extent due to the length and size of the river, insufficient monitoring resources, and its multi-jurisdictional nature. The Oti basin is affected mainly by both domestic and agricultural activities. Pollution is generally slight and localized along the banks owing to indiscriminate disposal of untreated faecal matter and garbage, because of lack of adequate sanitary and waste disposal facilities (WRC, 2000).

The environmental issues arise from the improper management and control of domestic, municipal, agricultural and industrial wastes which find their way into the water bodies, as well as from erosion in river catchments as a result of clearing for farming, timber, and extraction of firewood, among others (WRC, 2000).

The ever-increasing demands that the society places on the ecosystem of the Oti river basin, coupled with the need to generate useful and convincing information in the design of socially optimal decisions for public intervention give good reason for the study.

The overall aim of the study was to determine the status of the Oti river water quality. The specific objectives of the study were: 1 . To study the physico-chemical and bacteriological characteristics of the Oti river; 2 . To propose recommendations for the efficient management of the river ecosystem.

\section{Materials and methods}

Study area

The study was conducted in the Oti arm of the Volta river basin. The Oti river begins in the Atakora Mountains at Boom, a forest reserve in Northern Benin, as River Pendjari. It passes through, and flows along, the border of Burkina Faso with Benin, Northern Togo highlands to Ghana, and finally drains into the Volta lake to the east of Kete Krachi (Fig. 1). 


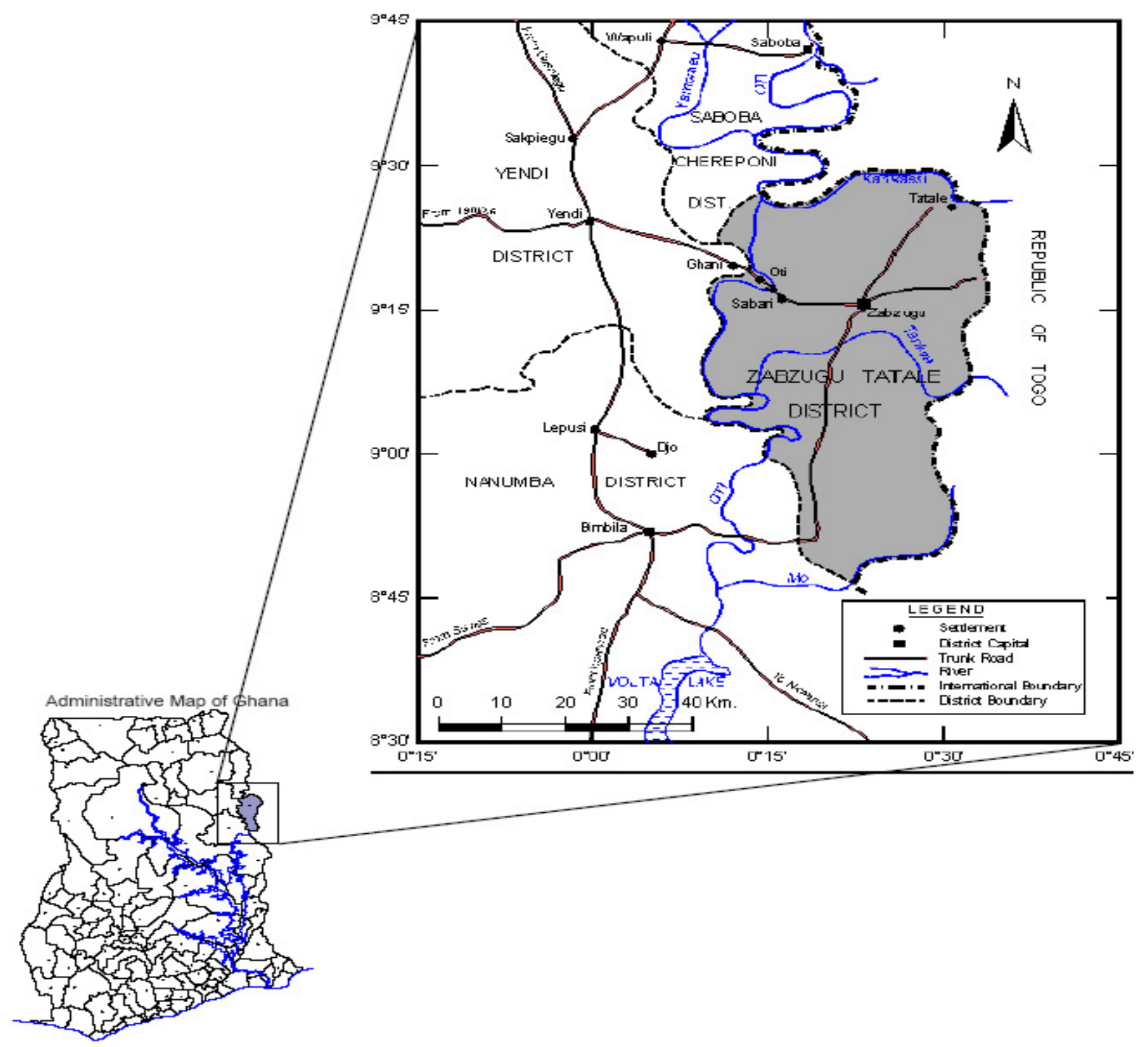

Fig. 1. Map of Ghana showing the Oti arm of the Volta basin

The Oti basin is found along the eastern fringes of the Northern Region of Ghana, across the middle belt to the northern portions of the Volta Region. Latitudinally, it extends from about $10^{\circ} 50^{\prime} \mathrm{N}$ to around $7^{\circ} 30^{\prime} \mathrm{N}$. It covers parts of Nalerigu, Gushiegu, Cheriponi, Yendi, Bimbila, Salaga and the whole of Saboba and Zabzugu townships in the Northern Region, and parts of Kete-Krachi Local Council in the Volta Region.

The total area of the basin is 17,942 $\mathrm{km}^{2}$ and a total length of $936.7 \mathrm{~km}$. The Oti basin in Ghana falls mainly in the Rural Savanna Geographic Division, which contributes up to $45.5 \%$ to national poverty levels (GSS, 2000). The mean annual inflow of the river into Ghana is about $276 \mathrm{~m}^{3} / \mathrm{s}$ (Opoku-Ankomah, 1998; WARM, 1998). It has a permanent flow, though most of its tributaries dry up during the dry season. The tributaries in Ghana include So, Mo and Kpasa rivers. Land-use is mainly extensive bush fallow and grazing (GEF-UNEP, 2002). The study district was the Zabzugu-Tatale District of the Northern Region of Ghana. The Sabari and Oti townships were the sampling locations.

\section{Climate and vegetation}

The climate of the Northern Region is relatively dry, with a single rainy season that begins in May and ends in October. The amount of rainfall recorded annually varies between $750 \mathrm{~mm}$ and $1050 \mathrm{~mm}$. The dry season starts in November and ends in March/April, with maximum temperatures occurring towards the end of the dry season (March-April) and minimum temperatures in December and January. The harmattan winds, which occur during the months of December to early February, have considerable effect on the temperatures in the region, which may vary between $14{ }^{\circ} \mathrm{C}$ at night and $40{ }^{\circ} \mathrm{C}$ during the day. Humidity, however, which is very low, mitigates the effect of the daytime heat. The main vegetation is classified as vast areas of grassland, interspersed with Guinea savanna woodland, characterized by drought-resistant trees such as the acacia, baobab, shea, dawadawa, mango and neem (GSS, 2005).

West African Journal of Applied Ecology, vol. 15, 2009 
A reconnaissance survey of the sampling points was carried out in November 2005. Two sampling sites were earmarked, namely upstream and downstream. Upstream site was supposed to be the point before any major activities in the sampling area whilst downstream point was after most of the major activities.

Water samples were collected on a bimonthly basis for a period of 6 months (December-May). At each sampling point, a clean 1-litre polyethylene sample bottle was filled with water. This was, subsequently, used in the laboratory for off site analysis. For dissolved oxygen (DO) determinations, separate samples were collected into $300 \mathrm{ml}$ plain glass bottles and the DO fixed using the azide modification of Winkler's method. Samples for biological oxygen demand (BOD) were collected into dark glass bottles for incubation and subsequent DO determination. Samples for bacteriological analyses were collected into sterilized plain glass bottles.

The water samples were kept at $4{ }^{\circ} \mathrm{C}$ in ice chest and transported to the laboratory of the field station of the CSIR-Water Research Institute, Tamale, on the same day of collection for analysis. Sampling bottles had appropriate labels on them, and record was made of each bottle. The samples were refrigerated, upon receipt in the laboratory, to avoid external contamination or deterioration, until the time of the analysis.

All the analyses were based on standard methods as appropriate to each water quality parameter, as prescribed in the APHA et al. (1998). Conductivity was measured with Cybersan 510 conductivity meter and turbidity with a HACH 2100 P Turbidimeter. Sodium and potassium were measured by flame emission photometry, trace metals by atomic absorption spectrophotometer, calcium and magnesium by EDTA titration, sulphate by the turbidimetric method, and chloride by argentometric titration.

Other analyses included alkalinity by strong acid titration method. Nutrients (nitrate-nitrogen and phosphate-phospho-rous) were determined using Dionex-80 ion analyzer and ammonium by direct nesslerisation and spectrophotometric determination at $410 \mathrm{~nm}$. Fluoride was determined by the SPADNS method. Total and faecal coliforms were determined by membrane filtration method using M-Endo-Agar Les (Difco) at $37{ }^{\circ} \mathrm{C}$ and on MFC Agar at $44{ }^{\circ} \mathrm{C}$, respectively. Pearson's rank correlation was also used to establish relations between parameters in the Densu basin. All tests were two-tailed. The analyses were executed by SPSS (version 12 for Windows, year 2003).

Each sample was analyzed for the following parameters: $p \mathrm{H}$, conductivity, turbidity, alkalinity, chloride, sulphate, nitrate-N, phosphate, fluoride, total hardness, dissolved oxygen, BOD, total iron, manganese, total coliform and faecal coliform. The values of these parameters were compared to the Ghana Raw Water Criteria and Guidelines (WRC, 2003).

\section{Results and discussion}

The physico-chemical and bacteriological characteristics of Oti river are presented in Fig. 2a and 2b, and Tables 1 and 2. The parameters are discussed based on variations upstream and downstream, as well as variations during the sampling months.

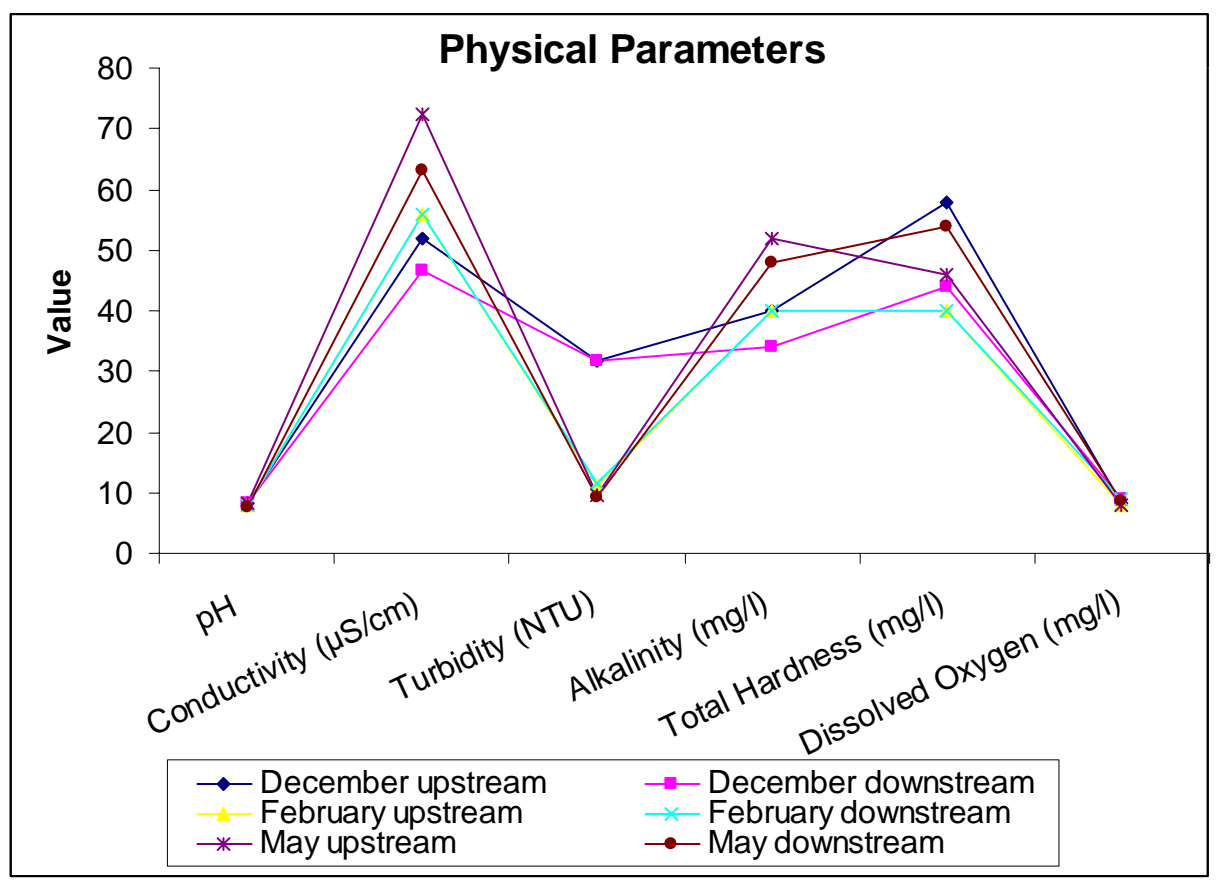

Fig. 2a. Physical parameters of the Oti river 


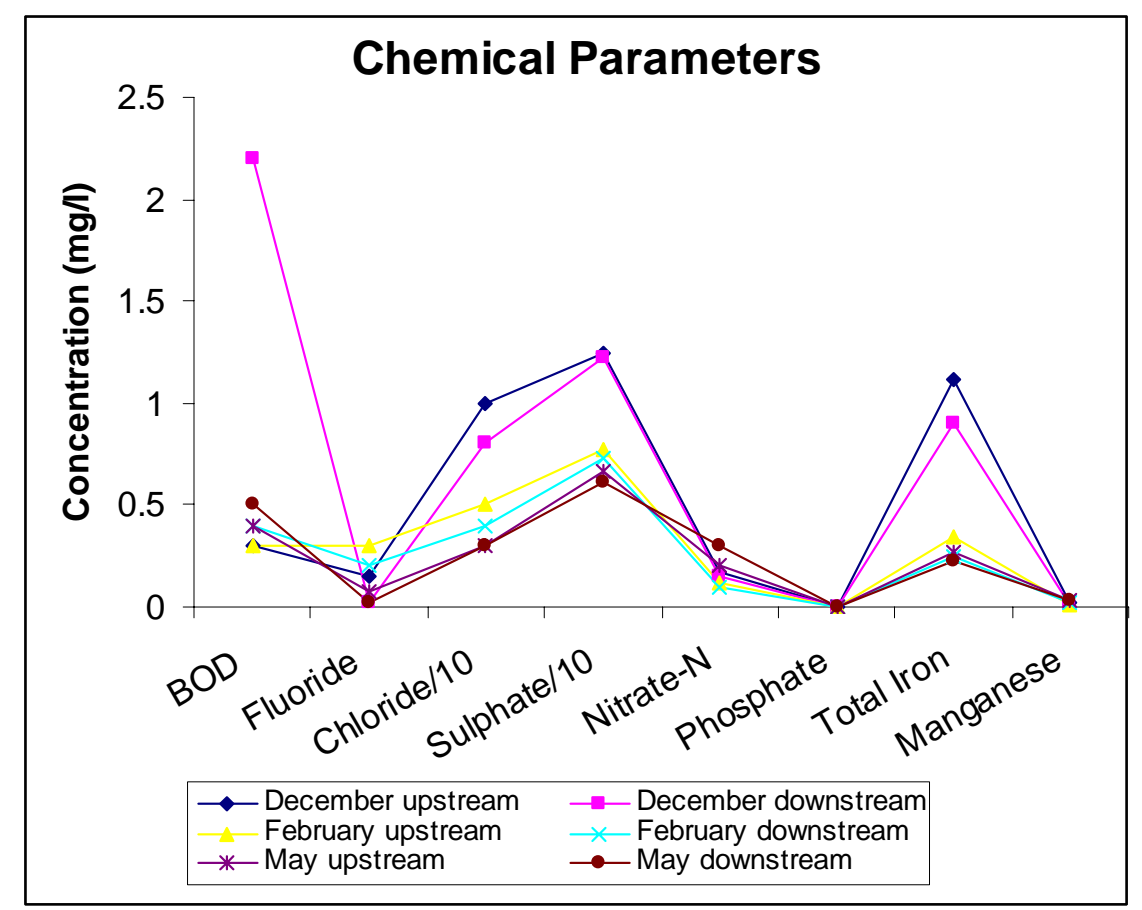

Fig. 2b. Chemical parameters of the Oti river

TABLE 1

Mean $( \pm S D)$ physical and selected chemical parameters of the Oti river

\begin{tabular}{|c|c|c|c|c|c|}
\hline \multirow[t]{2}{*}{ Parameter } & \multicolumn{2}{|l|}{ Upstream (US) } & \multicolumn{3}{|c|}{ Downstream (DS) } \\
\hline & $M e a n \pm S D$ & Maximum & $M e a n \pm S D$ & Minimum & Maximum \\
\hline \multicolumn{6}{|l|}{ Physical parameters } \\
\hline$p \mathrm{H}$ & $8.150 \pm 0.207 .920$ & 8.290 & $7.943 \pm 0.32$ & 7.870 & 8.290 \\
\hline Conductivity $(\mu \mathrm{S} / \mathrm{cm})$ & $60.067 \pm 10.9651 .800$ & 072.500 & $55.233 \pm 8.26$ & 46.700 & 55.800 \\
\hline Turbidity (NTU) & $17.540 \pm 12.299 .620$ & 31.700 & $17.600 \pm 12.43$ & 11.500 & 31.900 \\
\hline Alkalinity (mg/l) & $44.000 \pm 6.9340 .000$ & 52.000 & $40.667 \pm 7.02$ & 34.000 & 40.000 \\
\hline Total hardness (mg/l) & $48.000 \pm 9.1740 .000$ & 58.000 & $46.000 \pm 7.21$ & 40.000 & 44.000 \\
\hline D. oxygen (mg/l) & $8.033 \pm 0.237 .900$ & 8.300 & $8.800 \pm 0.17$ & 9.800 & 8.900 \\
\hline \multicolumn{6}{|l|}{ Chemical parameters } \\
\hline BOD (mg/l) & $0.333 \pm 0.060 .300$ & 0.400 & $1.033 \pm 1.01$ & 0.400 & 2.200 \\
\hline Fluoride (mg/l) & $0.177 \pm 0.110 .080$ & 0.300 & $0.080 \pm 0.10$ & 0.020 & 0.200 \\
\hline Chloride (mg/l) & $6.000 \pm 3.613 .000$ & 10.000 & $5.000 \pm 2.65$ & 4.000 & 8.000 \\
\hline Sulphate (mg/l) & $8.933 \pm 3.046 .700$ & 12.400 & $8.533 \pm 3.23$ & 7.300 & 12.200 \\
\hline Nitrate-N (mg/l) & $0.163 \pm 0.040 .120$ & 0.200 & $0.183 \pm 0.10$ & 0.100 & 0.150 \\
\hline Phosphate (mg/l) & $0.001 \pm 0.000 .001$ & 0.001 & $0.001 \pm 0.00$ & 0.001 & 0.000 \\
\hline Total iron (mg/l) & $0.577 \pm 0.470 .270$ & 1.120 & $0.460 \pm 0.38$ & 0.250 & 0.900 \\
\hline Manganese (mg/l) & $0.024 \pm 0.010 .013$ & 0.037 & $0.021 \pm 0.01$ & 0.016 & 0.017 \\
\hline
\end{tabular}


TABLE 2

Mean counts ( $\pm S D$ ) of bacteriological parameters of the Oti river

\begin{tabular}{lcccccc}
\hline Parameter & \multicolumn{2}{c}{$\begin{array}{c}\text { Upstream (US) } \\
\text { Mean } \pm S D\end{array}$} & Minimum & Maximum & Mean $\pm S D$ & Mownstream (DS) \\
& & & & & & \\
& & & & & \\
$\begin{array}{l}\text { Total coliform } \\
(\mathrm{cfc} / 100 \mathrm{ml})\end{array}$ & $5606.667 \pm 4259.77$ & 770 & 8800 & $5503.333 \pm 3985.13$ & 920 & 8150 \\
$\begin{array}{l}\text { Faecal coliform } \\
(\mathrm{cfc} / 100 \mathrm{ml})\end{array}$ & $201.000 \pm 232.06$ & 12 & 460 & $243.333 \pm 174.04$ & 56 & 274 \\
\hline
\end{tabular}

\section{Physical parameters}

The results obtained for the physical parameters are shown in and Fig. 2a and Table 1. The variations of $p \mathrm{H}$ among the sampling months and along the course of the river (between upstream and downstream) were statistically insignificant at the 5\% level (Appendices A and B).

The $p \mathrm{H}$ for the water samples ranged from a minimum of 7.87 in February to a maximum of 8.29 in December and May. Downstream values were lower than upstream values in all the sampling periods. The generally higher values of the $\mathrm{pH}$ could be due to the release of acid-forming substances such as sulphate, phosphate, nitrates, etc. into the water. These substances might have altered the acid-base equilibria and resulted in the reduced acid-neutralizing capacity and, hence, raising the $p \mathrm{H}$.

The $p \mathrm{H}$ was relatively lower in February, which was the peak of the dry season, when the water level as well as the flow rate was very low. This could be because the discharges from the farm fields stay longer in the water column as the flow rate was slow. The $p \mathrm{H}$ values were within the "no effect" range of 6.0-9.0 for drinking water use (WRC, 2003). Though the selection of raw water as a drinking water source is never based on solely $p \mathrm{H}$, these results show that no significant adverse health effects, due to toxicity of dissolved metal ions and protonated species, and no aesthetic effects (e.g. taste), were expected.

Conductivity. The variations of conductivity among the sampling months were statistically significant at the $5 \%$ level. However, variations along the course of the river (between upstream and downstream) were statistically insignificant at the 5\% level (Appendices A and B). Conductivity ranged from a minimum of 46.7 $\mu \mathrm{S} / \mathrm{cm}$ in December to a maximum of $72.5 \mu \mathrm{S} / \mathrm{cm}$ in May. The high conductivity recorded in May could be because of domestic effluent discharges and surface run-off from the cultivated fields which might have increased the concentration of ions. Conductivity was higher upstream than downstream. This could be that the ions were very mobile since the conductivity values for February (the peak of the dry season when flow rates were low) were almost the same upstream and downstream.

Almost all the conductivity values fell within the "no effect" range of 0-70 $\mu \mathrm{S} / \mathrm{cm}$ for drinking water use (WRC, 2003). This indicates that no adverse health effects associated with the electrical conductivity of the water were expected. However, since all the conductivity values were higher than the taste threshold of 45 $\mu \mathrm{S} / \mathrm{cm}$, a slight salty taste was expected. There was a positive correlation between conductivity and alkalinity ( $r=0.906, P<0.05)$, and manganese $(r=0.851, P<0.05)$. This was expected because the properties of conductivity are governed by the characteristics of the constituents inorganic salts dissolved in water.

Turbidity. The variations of turbidity among the sampling months were statistically significant at the 5\% level. However, variations along the course of the river (between upstream and downstream) were statistically insignificant at the 5\% level (Appendices A and B). Turbidity values ranged from a minimum of $9.62 \mathrm{NTU}$ in May to a maximum of 31.90 NTU in December. December recorded the highest values because the volume of the water was getting smaller as the dry season was reaching its peak and most of the tributaries were getting turbid because of anthropogenic activities. Hence, more soil particles, which constitute the major part of suspended matter contributing to the turbidity in most natural waters, were discharged into, or displaced in, the water. The lower values recorded in February can be that, at that time, all the tributaries had dried up, thus, reducing the influx of suspended matter. The low values recorded in May, which was the beginning of the rainy season, could have been due to dilution by the rainwater.

Turbidity values were, generally, as expected, higher upstream than down-stream. This is because most of the anthropogenic activities take place between upstream and downstream. These activities discharge suspended matter into the water and displace the settled matter.

The turbidity values for December and February (both in the dry season) were far higher than the "no effect" range of 0-1 NTU for drinking water use (WRC, 2003). This indicates that in the dry season, the water carried an associated risk of disease transmission due to infectious disease agents and chemicals absorbed 
onto particulate matter. In addition, turbidity was visible and had aesthetic effects on appearance. However, although turbidity values in May (rainy season) were lower, it was still higher than the "no effect" range for drinking water use.

There was a positive correlation between turbidity and chloride $(r=0.954, P<0.01)$, sulphate $(r=0.992$, $P<0.01)$, and total iron $(r=0.979, P<0.01)$.

Total alkalinity. The variations of total alkalinity among the sampling months were statistically significant at the $5 \%$ level. However, variations along the course of the river (between upstream and downstream) were statistically insignificant at the $5 \%$ level (Appendices A and B). Alkalinity values ranged from a minimum of $34.0 \mathrm{mg} / \mathrm{l}$ in December to a maximum of $52.0 \mathrm{mg} / \mathrm{l}$ in May. In the absence of sufficient carbonic acid, the bicarbonate ion in the water dissociates to form additional carbon dioxide (Baird, 2000). Algae readily exploit this carbon dioxide for their photosynthetic needs, at the cost of allowing a build-up of hydroxide ions to such an extent that the water becomes quite alkaline. This can account for the high alkalinity values recorded, especially in May.

There was a general decrease in alkalinity along the river course probably due to the reaction of the excess hydroxide ions with other reactive species in the river course. These values indicate that the river had the potential to resist acidification. There was a positive correlation between alkalinity and conductivity $(r=$ $0.977, P<0.05)$, and manganese $(r=0.906, P<0.05)$. This was so because both alkalinity and conductivity relate to the number of ions in solution. The correlation between alkalinity and manganese could be because of the potential of manganese to form salt compounds with basic anions.

Total hardness. The variations of total hardness among the sampling months and along the course of the river (between upstream and downstream) were statistically insignificant at the $5 \%$ level (Appendices A and B).

Values ranged from a minimum of $40.0 \mathrm{mg} / \mathrm{l}$ in February to a maximum of $58.0 \mathrm{mg} / \mathrm{l}$ in December. The high values recorded could be due to the high temperature in December and the early rains in May. Along the river course, the upstream value was higher than downstream value in December. The values were the same for both upstream and downstream in February.

The solubility of salts is a function of temperature. Hence, the value for upstream was higher than that of downstream in December since the salts might have been solubilized along the river course. However, the higher value for downstream in May could be because of increased anthropogenic activities, e.g. farming as the rains set in. Following WRC (2003), the water can be described as being soft to moderately soft since some of the values recorded fell within the soft to moderately soft range of $0-100 \mathrm{mg} / \mathrm{l}$.

Dissolved oxygen. The variations of dissolved oxygen (DO) among the sampling months were statistically insignificant at the 5\% level. However, variations along the course of the river (between upstream and downstream) were statistically significant at the 5\% level (Appendices A and B). Dissolved oxygen values ranged from a minimum of $7.90 \mathrm{mg} / \mathrm{l}$ in February and May to a maximum of $8.90 \mathrm{mg} / \mathrm{l}$ in December and February. The values of DO downstream were higher than upstream values in all the sampling months.

According to the USDA (1992), the level of oxygen depletion depends primarily on the amount of waste added, the size, velocity and turbulence of the stream, the initial DO level in the water and in the stream, and the temperature of the water. Following this, the higher DO values downstream could be due to the velocity and the more turbulent nature of the stream from anthropogenic activities (such as bathing, washing, water abstraction, etc.) occurring in between upstream and downstream.

\section{Chemical parameters}

Results obtained for the chemical parameters are shown in Fig. 2b and Table 1 .

Biochemical oxygen demand. The variations of biochemical oxygen demand (BOD) among the sampling months and along the course of the river (between upstream and downstream) were statistically insignificant at the 5\% level (Appendices A and B). Values ranged from a minimum of $0.3 \mathrm{mg} / \mathrm{l}$ in December and February to a maximum of $2.2 \mathrm{mg} / \mathrm{l}$ in December. The high BOD value in December may be due to discharge of organic wastes (e.g. refuse, human and animal excreta, soap, etc.) into the water, resulting in the uptake of oxygen in the oxidative breakdown of these wastes. The same reason can be attributed to the generally higher values of BOD down-stream. This could have unfavourably affected aquatic life.

Chloride. The variations of chloride among the sampling months were statistically significant at the $5 \%$ level. However, variations along the course of the river (between upstream and downstream) were statistically insignificant at the 5\% level (Appendices A and B). Chloride values ranged from a minimum of $3.0 \mathrm{mg} / \mathrm{l}$ in May to a maximum of $10.0 \mathrm{mg} / \mathrm{l}$ in December. The high values recorded in December could be due to 
irrigation return flows. The lower values in May could be because there were little or no irrigation return flows, as it was just the beginning of the rainy season.

All the values recorded were within the "no effect" range of 0-100 mg/l for drinking water use (WRC, 2003). This means that no adverse health effects, no aesthetic effects, and no effects on household items were expected. There was a positive correlation between chloride and turbidity $(r=0.954, P<0.01)$, sulphate $(r=$ $0.974, P<0.01)$ and total iron $(r=0.981, P<0.01)$. This is because chloride reacts with iron and, hence, accelerates the corrosion rate of metals. This reaction results in the formation of colloids and, for that matter, turbidity. The correlation between chloride and sulphate suggests that they are from similar sources.

Sulphate. The variations of sulphate among the sampling months were statistically significant at the $5 \%$ level (Appendices A and B). Sulphate values ranged from a minimum of $6.10 \mathrm{mg} / \mathrm{l}$ in May to a maximum of $12.40 \mathrm{mg} / \mathrm{l}$ in December. Sulphates, when added to water, tend to accumulate to progressively increasing concentration (WRC, 2003). This could account for the high levels recorded in December. Under anaerobic conditions, bacteria use sulphate as an oxygen source (Peirce et al., 1998). This can account for the lower values recorded in February as the DO levels were slightly lower than in December. The much lower sulphate values recorded in May could be because sulphate easily precipitates and settles to the bottom sediment of the river as reported by Mathuthu et al. (1997).

The observed variations along the river course (between upstream and downstream) were not statistically significant at the 5\% level. All the sulphate values fell within the "no effect" range of 0-200 mg/l for drinking water use (WRC, 2003). This implies that no adverse health and aesthetic effects were expected.

Sulphate forms soluble and insoluble salt with various cations. These salts impart on turbidity. Hence, the positive correlation between sulphate and turbidity $(r=0.992, P<0.01)$, and total iron $(r=0.979, P<0.01)$ was expected. The correlation between sulphate and chloride suggest that they are from similar sources.

Nitrate- $N$. The variations of nitrate- $\mathrm{N}$ among the sampling months and along the course of the river (between upstream and downstream) were statistically insignificant at the $5 \%$ level (Appendices A and B). Nitrate- $\mathrm{N}$ values ranged from a minimum of $0.1 \mathrm{mg} / \mathrm{l}$ in February to a maximum of $0.37 \mathrm{mg} / \mathrm{l}$ in May. The high levels of nitrate recorded in May might have been because of surface run-off from farms and animal pens into the river from the early rains. All the nitrate values were within the "no effect" range of 0-6 mg/l for drinking water use (WRC, 2003). This indicates that no adverse health effects were expected during the sampling months.

Phosphate. In all the sampling locations and times, phosphate was detected to be less than $0.01 \mathrm{mg} / \mathrm{l}$ probably due to the detection limit $(<0.01 \mathrm{mg} / \mathrm{l})$ of the method used. This indicates that the farmers along the riverbanks probably did not use N-P-K fertilizer, at least during the sampling period, which has the potential of being leached or washed into the river.

Fluoride. The variations of fluoride among the sampling months and along the course of the river (between upstream and downstream) were statistically insignificant at the $5 \%$ level (Appendices A and B). Fluoride values ranged from a minimum of $0.02 \mathrm{mg} / \mathrm{l}$ in all the sampling months to a maximum of $0.30 \mathrm{mg} / \mathrm{l}$ in February. Fluoride values were the same downstream in December and May. Slightly higher and different values were recorded upstream. The lower values recorded downstream could be as a result of the pronounced electron affinity of the fluoride atom. It might have reacted with most reactive species along the course of the river, hence, its depletion downstream.

No adverse health effects or tooth damages are expected since the values fell within the "no effect" range of $0-1 \mathrm{mg} / \mathrm{l}$ for drinking water use (WRC, 2003). There was a negative correlation between fluoride and total coliform ( $r=-0.864, P<0.05)$, and faecal coliform $(r=-0.846, P<0.05)$. This was a priori expected because fluoride inactivates bacteria by interfering with their enzymes (i.e. fluoride has a bactericidal effect). At $p \mathrm{H}$ 6.7 and 7.8, the oxidation of glucose, fructose, and trehalose in bacteria is increased by fluoride. In large concentra-tions, inorganic and organic fluoride compounds inhibit growth of bacteria. At slightly lower $p \mathrm{H}$, 0.05-0.10 mg, fluoride inhibits the oxidation of these sugars and, hence, inhibits growth (Fitzgerald \& Bernheim, 1984).

Total iron. The variations of total iron among the sampling months were statistically significant at the $5 \%$ level. However, variations along the course of the river (between upstream and downstream) were statistically insignificant at the 5\% level (Appendices A and B).

Total iron values ranged from a minimum of $0.23 \mathrm{mg} / \mathrm{l}$ in May to a maximum of $1.12 \mathrm{mg} / \mathrm{l}$ in December. The concentration of dissolved iron in water is dependent on the $p \mathrm{H}$, redox potential, turbidity, suspended matter, the concentration of aluminium and the occurrence of several heavy metals, notably manganese (WRC, 2003). Hence, the high values recorded in December can be attributed to the high turbidity and $p \mathrm{H}$ levels recorded in the same month. This implies that iron and turbidity were from similar pollution source. The values of iron, however, decreased along the course of the river. This can be attributed to the precipitation West African Journal of Applied Ecology, vol. 15, 2009 
of iron, as well as a natural cycling of iron, between the dissolved and precipitated phases at the watersediment interface.

All the values recorded fell outside the "no effect" range of $0-0.3 \mathrm{mg} / \mathrm{l}$ for drinking water use (WHO, 1995). The values, however, fell within the $0.1-10 \mathrm{mg} / \mathrm{l}$ range for which slight adverse health effects can be expected in children and sensitive individuals (WRC, 2003). Gradual increase in adverse aesthetic effects, e.g. taste, could also be expected. There was a positive correlation between total iron and turbidity $(r=0.979, P<$ $0.01)$, sulphate $(r=0.979, P<0.01)$, and chloride $(r=0.981, P<0.01)$.

Manganese. The variations of manga-nese among the sampling months were statistically significant at the $5 \%$ level (Appendices A and B). Manganese values ranged from a minimum of $0.13 \mathrm{mg} / \mathrm{l}$ in February to a maximum of $0.37 \mathrm{mg} / \mathrm{l}$ in May. Manganese dissolves from sediments under anaerobic conditions and reprecipitates under aerobic conditions (WRC, 2003). The high levels of manganese in May could be due to the relatively low dissolved oxygen levels in the same month that could have caused the manganese to dissolve from the sediments.

Variations of manganese along the course of the river (between upstream and downstream) were statistically insignificant at the 5\% level (Appendices A and B). However, the levels of manganese decreased along the course of the river probably due to the re-precipitation of the manganese as aerobic conditions improve along the river course. All the values of manganese recorded were within the "no effect" range of 0 $0.05 \mathrm{mg} / \mathrm{l}$ for drinking water (WRC, 2003). Hence, no adverse health effects could be expected. However, marginal aesthetic problems could be expected since some of the values were within the $0.02-0.05 \mathrm{mg} / \mathrm{l}$ range at which marginal aesthetic problems could occur.

There were positive correlations between manganese and conductivity $(r=0.851, P<0.05)$, and alkalinity $(r=0.906, P<0.05)$. This was explained earlier under alkalinity. Manganese can be utilized by metallophilic bacteria (WRC, 2003), hence, the correlation between manganese and faecal coliforms.

\section{Bacteriological parameters}

Results obtained for the bacteriological parameters are shown in Table 2.

Total coliforms. Total coliform counts ranged from a minimum of $770 \mathrm{cfc} / 100 \mathrm{ml}$ in February to a maximum of $8800 \mathrm{cfc} / 100 \mathrm{ml}$ in May. The variations among the sampling months were statistically significant at the $5 \%$ level. However, variations along the course of the river (between upstream and downstream) were statistically insignificant at the 5\% level (Appendices A and B). The counts in May (early rainy season) can be attributed to surface run-off and domestic waste waters. Downstream counts were higher in December and February than upstream counts in the same months. This can be attributed to various anthropogenic activities (such as defecation, surface run-off, waste discharges, etc.) that take place between upstream and downstream.

All the values recorded fell well out of the "no effect" range of $0-5 \mathrm{cfc} / 100 \mathrm{ml}$ for domestic water use (WRC, 2003). These values indicate significant and increasing risk of infectious disease transmission when the water is used for domestic purposes. There was a positive correlation between total coliform and faecal coliform $(r=0.839, P<0.05)$, and a negative correlation between total coliform and fluoride $(r=-0.846, P<$ 0.01). This was explained earlier under fluoride.

Faecal coliforms. Faecal coliforms have been shown to represent 93-99\% of coliform bacteria in faeces from humans, poultry, cats, dogs and rodents (WRC, 2003). The variations among the sampling months were statistically significant at the $5 \%$ level. However, variations along the course of the river (between upstream and downstream) were statistically insignificant at the 5\% level (Appendices A and B).

Faecal coliform counts ranged from a minimum of $12 \mathrm{cfc} / 100 \mathrm{ml}$ in February to a maximum of $460 \mathrm{cfc} / 100$ $\mathrm{ml}$ in May. The high counts of faecal coliforms can be attributed to the indiscriminate defecation along the river banks by both humans and other animals that graze along the river banks. The particularly high counts in May can be attributed to the large flocks of birds that were present in that month. Jones \& White (1984) reported that birds "pollute" more faecal indicators than humans.

Downstream counts were higher than upstream counts in December and February. This was expected as the level of pollution from faecal coliforms increase along the stretch of the river as a result of indiscriminate defecation. However, the downstream counts in May were lower than upstream counts. This can be attributed to the increased flow rates in that month as most of the tributaries started discharging into the river.

The counts of faecal coliforms in almost all occasions of sampling indicate significant and increasing risk of infectious disease transmission. As faecal coliform levels increase beyond $20 \mathrm{cfc} / 100 \mathrm{ml}$, the amount of water ingested required to cause infections decreases (WRC, 2003).

There were positive correlations between faecal coliform and manganese ( $r=0.864, P<0.05)$, and total coliform whilst negative correlations were recorded between faecal coliform and fluoride $(r=-0.846, P<$

West African Journal of Applied Ecology, vol. 15, 2009 
0.01) as earlier on explained under fluoride. Similar contaminations from direct human and animal excreta were observed by Karikari \& Ansa-Asare (2004) in the Densu river of Ghana.

\section{Water quality index}

Water quality index (WQI) was used to assess water quality relative to the standard for domestic use and to provide insight into the degree to which water quality is affected by human activity. Using the WQI calculator 1.0 (CCME, 2001), the WQI for the Oti river was calculated to be 39.3. The WQI indicates that water quality in the Oti river was poor. This implies that the water quality (Table 3) is almost always threatened or impaired; conditions usually depart from natural or desirable levels.

TABLE 3

Classification of water quality

\begin{tabular}{ll}
\hline Class & WQI range \\
\hline Excellent & $95-100$ \\
Good & $80-94$ \\
Fair & $65-79$ \\
Marginal & $45-64$ \\
Poor & $0-44$ \\
\hline
\end{tabular}

Source: CCME, 2001

\section{Conclusion}

The study has provided useful baseline information on the water quality of the Oti arm of the Volta lake for the management of the ecosystem as well as the ecosystem of the entire Volta basin, especially given the current mandate of the GLOWA Volta Basin Project, which is to support sustainable water resource management in the riparian countries of the Volta basin in West Africa.

The study enabled the definition of existing conditions, and provides a basis for trends detection as well as information for determining cause-and-effect relations with respect to, for example, waste disposal and anthropogenic activities in and along the river. Farmers farming along the riverbanks probably do not use NPK fertilizer, or they use it in very small quantities, given the fact that phosphates were almost absent (less than $0.01 \mathrm{mg} / \mathrm{l}$ ) in the water samples that were analyzed.

It is concluded that the Oti river water is not suitable for direct human consumption at all the sampled locations, in view of the high counts of both faecal coliforms (minimum of 12 and maximum of $460 \mathrm{cfc} / 100$ $\mathrm{ml}$ ) and total coliforms (minimum of 770 and maximum of $8800 \mathrm{cfc} / 100 \mathrm{ml}$ ). With the exception of turbidity and total iron, all the other water quality parameters were within the limits set out by the 2003 Ghana Raw Water Criteria and Guidelines for domestic water use and the 1995 World Health Organisation standards for drinking water.

\section{Recommendations}

The study recommends that the District Assembly and other stakeholders should provide sanitary facilities in the area to control river pollution. Appropriate water treatments or safe potable water sources should be provided in the area to improve the welfare of the riparian dwellers. There is the need to educate the public on efficient water use methodologies and the intensifi-cation of the educational awareness as to how to handle and locally treat water for domestic use. In view of the importance of the Oti river ecosystem, stringent efforts should be made to, on regular basis, monitor the water quality of the river as well as the landscape in order to conserve the ecosystem.

\section{Acknowledgement}

The authors thank Dr O. Ansa-Asare, Senior Research Scientist, at Water Research Institute (WRI) as well as Mr Cobbina and Mr A-Latif both of the WRI, Tamale Field Station, for their valiant and diligent assistance. The authors also thank Mr Congo (Agric. Officer, Zabzugu), Afa Musah and Faruku.

\section{References}

APHA, AWWA and WEF (1998). Standard Methods for the Examination of Water and Wastewater, 20th edn. Washington, D.C. Baird C. (2000). Environmental Chemistry, 2nd edn. W.H. Freeman and Company. New York. 557 pp.

Canadian Council of Ministers of the Environment (CCME) (2001). Canadian Water Quality Guidelines for the Protection of Aquatic Life: CCME Water Quality Index 1.0. CCME, Winnipeg. 
Fitzgerald R. J. and Bernheim F. (1984). The Effect of Sodium Fluoride on the Metabolism of Certain Mycobacteria. Department of Physiology and Pharmacology, Duke University School of Medicine, Durham, North Carolina.

GEF-UNEP (2002). Volta River Basin Preliminary Strategic Action Programme. Final Report. Project Development Facility (PDFB) Global Environment Facility-United Nations Environment Programme, Accra, Ghana.

Ghana Statistical Service (GSS) (2000). Poverty Trends in Ghana in the 1990's. GSS, Accra, Ghana.

Ghana Statistical Service (GSS) (2005). 2000 Population and Housing Census Reports, Analysis of District Data and Implications for Planning- Northern Region. Ghana Statistical Service, Accra, Ghana.

Jones F. and White W. R. (1984). Health Amenity Aspects of Surface Water. Wat. Pollut. Control 83: 215-225.

Karikari A. Y. and Ansa-Asare O. D. (2006). Physico-Chemical and Microbial Water Quality Assessment of Densu River of Ghana. West Afr. J. appl. Ecol. 10: 87-100.

Mathuthu A. S., Mwanga K. and Simoro A. (1997). Impact assessment of industrial and sewage effluents on the water quality of the receiving Marimba River in Harare. In Lake Chivero: A Polluted Lake. (N. A. G. Moyo, ed.), pp. 43-52. University of Zimbabwe Publications, Harare, Zimbabwe.

Moxon J. (1968). Volta, Man's Greatest Lake. The Story of Ghana’s Akosombo Dam. Andre Deutsch Ltd, London, UK. 256 pp.

Opoku-Ankomah Y. (1998). Surface Water Resources. In Water Resources Management Study Information 'Building Block' Study, Part II, Vol.2. Information in the Volta Basin System (Final Report). Nii Consult, Accra, Ghana.

Peirce J., Weiner R. F. and Vesilind P. A. (1998). Environmental Pollution and Control, 4th edn. Butterworth-Heineman, Boston. 400 pp.

United States Department of Agriculture (USDA) (1992). Agricultural Waste Management Building Design Handbook. Soil Conservation Service, Washington, D.C.

WARM (1998). Ghana's Water Resources Management: Challenges and Opportunities. Ministry of Works and Housing, Accra, Ghana.

Water Resources Commission (WRC) (2000). Water Resources Management Problems Identification, Analysis and Prioritization. Final Report. WRC, Accra, Ghana.

Water Resources Commission (WRC) (2003). Ghana Raw Water Criteria and Guidelines, Vol. 1. Domestic Water. CSIR-Water Research Institute, Accra, Ghana.

World Health Organization (1995). WHO Guidelines for Drinking Water Quality, 2nd edn. WHO, Geneva. 
APPENDIX A

ANOVA of water quality parameters among the sampling methods

ANOVA a

\begin{tabular}{|c|c|c|c|c|c|c|}
\hline & & $\begin{array}{l}\text { Sum of } \\
\text { Squares }\end{array}$ & $d f$ & Mean Square & $\mathrm{F}$ & Sig. \\
\hline \multirow[t]{3}{*}{$\mathrm{pH}$} & Between Groups & .150 & 2 & .075 & 1.157 & .424 \\
\hline & Within Groups & .195 & 3 & .065 & & \\
\hline & Total & .345 & 5 & & & \\
\hline \multirow[t]{3}{*}{ Conduct ivity } & Between Groups & 355.680 & 2 & 177.840 & 9.484 & .050 \\
\hline & Within Groups & 56.255 & 3 & 18.752 & & \\
\hline & Total & 411.935 & 5 & & & \\
\hline \multirow[t]{3}{*}{ Turbidity } & Between Groups & 611.051 & 2 & 305.525 & 14276.888 & .000 \\
\hline & Within Groups & .064 & 3 & .021 & & \\
\hline & Total & 611.115 & 5 & & & \\
\hline \multirow[t]{3}{*}{ Alkalinity } & Between Groups & 185.333 & 2 & 92.667 & 10.692 & .043 \\
\hline & Within Groups & 26.000 & 3 & 8.667 & & \\
\hline & Total & 211.333 & 5 & & & \\
\hline \multirow[t]{3}{*}{ Chloride } & Between Groups & 39.000 & 2 & 19.500 & 23.400 & .015 \\
\hline & W ithin Groups & 2.500 & 3 & .833 & & \\
\hline & Total & 41.500 & 5 & & & \\
\hline \multirow[t]{3}{*}{ Sulphate } & Between Groups & 39.373 & 2 & 19.687 & 210.929 & .001 \\
\hline & Within Groups & .280 & 3 & .093 & & \\
\hline & Total & 39.653 & 5 & & & \\
\hline \multirow[t]{3}{*}{ Nitrate-N } & Between Groups & .020 & 2 & .010 & 5.593 & .097 \\
\hline & Within Groups & .005 & 3 & .002 & & \\
\hline & Total & .026 & 5 & & & \\
\hline \multirow[t]{3}{*}{ Phosphate } & Between Groups & .000 & 2 & .000 & . & \\
\hline & Within Groups & .000 & 3 & .000 & & \\
\hline & Total & .000 & 5 & & & \\
\hline \multirow[t]{3}{*}{ Flouride } & Between Groups & .046 & 2 & .023 & 4.489 & .125 \\
\hline & Within Groups & .015 & 3 & .005 & & \\
\hline & Total & .061 & 5 & & & \\
\hline \multirow[t]{3}{*}{ Total Hardness } & Between Groups & 148.000 & 2 & 74.000 & 1.708 & .320 \\
\hline & Within Groups & 130.000 & 3 & 43.333 & & \\
\hline & Total & 278.000 & 5 & & & \\
\hline \multirow[t]{3}{*}{ Dissolved Oxygen } & Between Groups & .123 & 2 & .062 & .200 & .829 \\
\hline & W ithin Groups & .925 & 3 & .308 & & \\
\hline & Total & 1.048 & 5 & & & \\
\hline \multirow[t]{3}{*}{ BOD } & Between Groups & .973 & 2 & .487 & .804 & .525 \\
\hline & W ithin Groups & 1.815 & 3 & .605 & & \\
\hline & Total & 2.788 & 5 & & & \\
\hline \multirow[t]{3}{*}{ Total iron } & Between Groups & .727 & 2 & .364 & 37.551 & .008 \\
\hline & Within Groups & .029 & 3 & .010 & & \\
\hline & Total & .756 & 5 & & & \\
\hline \multirow[t]{3}{*}{ Manganese } & Between Groups & .000 & 2 & .000 & 11.257 & .040 \\
\hline & Within Groups & .000 & 3 & .000 & & \\
\hline & Total & .000 & 5 & & & \\
\hline \multirow[t]{3}{*}{ Total coliform } & Between Groups & 66728700 & 2 & 33364350.000 & 74.638 & .003 \\
\hline & W ithin Groups & 1341050.0 & 3 & 447016.667 & & \\
\hline & Total & 68069750 & 5 & & & \\
\hline \multirow[t]{3}{*}{ Faecal coliform } & Between Groups & 157976.333 & 2 & 78988.167 & 18.239 & .021 \\
\hline & Within Groups & 12992.500 & 3 & 4330.833 & & \\
\hline & Total & 170968.833 & 5 & & & \\
\hline
\end{tabular}

a. The factor is the Sampling Month

West African Journal of Applied Ecology, vol. 15, 2009 
APPENDIX B

ANOVA of water quality parameters along the river course

ANOVA a

\begin{tabular}{|c|c|c|c|c|c|c|}
\hline & & $\begin{array}{l}\text { Sum of } \\
\text { Squares }\end{array}$ & df & Mean Square & $\mathrm{F}$ & Sig. \\
\hline \multirow[t]{3}{*}{$\mathrm{pH}$} & Between Groups & .064 & 1 & .064 & 912 & .394 \\
\hline & Within Groups & .281 & 4 & .070 & & \\
\hline & Total & .345 & 5 & & & \\
\hline \multirow[t]{3}{*}{ Conductivity } & Between Groups & 35.042 & 1 & 35.042 & .372 & .575 \\
\hline & Within Groups & 376.893 & 4 & 94.223 & & \\
\hline & Total & 411935 & 5 & & & \\
\hline \multirow[t]{3}{*}{ Turbidity } & Between Groups & .005 & 1 & .005 & .000 & .996 \\
\hline & Within Groups & 611110 & 4 & 152777 & & \\
\hline & Total & 611115 & 5 & & & \\
\hline \multirow[t]{3}{*}{ Alkalinity } & Between Groups & 16.667 & 1 & 16.667 & .342 & .590 \\
\hline & Within Groups & 194. 667 & 4 & 48.667 & & \\
\hline & Total & 211333 & 5 & & & \\
\hline \multirow[t]{3}{*}{ Chloride } & Between Groups & 1.500 & 1 & 1.500 & .150 & .718 \\
\hline & Within Groups & 40.000 & 4 & 10.000 & & \\
\hline & Total & 41.500 & 5 & & & \\
\hline \multirow[t]{3}{*}{ Sulphate } & Between Groups & .240 & 1 & .240 & .024 & .884 \\
\hline & Within Groups & 39.413 & 4 & 9.853 & & \\
\hline & Total & 39.653 & 5 & & & \\
\hline \multirow[t]{3}{*}{ Nitrate-N } & Between Groups & .001 & 1 & .001 & .096 & .772 \\
\hline & Within Groups & .025 & 4 & .006 & & \\
\hline & Total & .026 & 5 & & & \\
\hline \multirow[t]{3}{*}{ Phosphate } & Between Groups & .000 & 1 & .000 & . & . \\
\hline & Within Groups & .000 & 4 & .000 & & \\
\hline & Total & .000 & 5 & & & \\
\hline \multirow[t]{3}{*}{ Flouride } & Between Groups & .014 & 1 & .014 & 1.196 & .336 \\
\hline & Within Groups & .047 & 4 & .012 & & \\
\hline & Total & .061 & 5 & & & \\
\hline \multirow[t]{3}{*}{ Total Hardness } & Between Groups & 6.000 & 1 & 6.000 & .088 & .781 \\
\hline & Within Groups & 272000 & 4 & 68.000 & & \\
\hline & Total & 278.000 & 5 & & & \\
\hline \multirow[t]{3}{*}{ Dissdved Oxygen } & Between Groups & .882 & 1 & .882 & 21.160 & .010 \\
\hline & Within Groups & .167 & 4 & .042 & & \\
\hline & Total & 1.048 & 5 & & & \\
\hline \multirow[t]{3}{*}{ BOD } & Between Groups & .735 & 1 & .735 & 1.432 & .298 \\
\hline & Within Groups & 2.053 & 4 & .513 & & \\
\hline & Total & 2.788 & 5 & & & \\
\hline \multirow[t]{3}{*}{ Total iron } & Between Groups & .020 & 1 & .020 & .111 & .756 \\
\hline & Within Groups & .736 & 4 & .184 & & \\
\hline & Total & .756 & 5 & & & \\
\hline \multirow[t]{3}{*}{ Manganese } & Between Groups & .000 & 1 & .000 & .130 & .737 \\
\hline & Within Groups & .000 & 4 & .000 & & \\
\hline & Total & .000 & 5 & & & \\
\hline \multirow[t]{3}{*}{ Total cdiform } & Between Groups & 16016.667 & 1 & 16016.667 & .001 & .977 \\
\hline & Within Groups & 68053733 & 4 & 17013433.33 & & \\
\hline & Total & 68069750 & 5 & & & \\
\hline \multirow[t]{3}{*}{ Faecal coliform } & Between Groups & 2688.167 & 1 & 2688.167 & .064 & .813 \\
\hline & Within Groups & 168280.7 & 4 & 42070.167 & & \\
\hline & Total & 170968.8 & 5 & & & \\
\hline
\end{tabular}

a. The Factor is Sampling Location (Upstream or Downstream) 